\title{
Human-vegetation interactions during the Holocene in North America
}

\author{
Konrad Gajewski $^{1}$ (D) Björn Kriesche ${ }^{2} \cdot$ Michelle A. Chaput ${ }^{1} \cdot$ Rafal Kulik $^{3} \cdot$ Volker Schmidt $^{2}$
}

Received: 31 August 2018 / Accepted: 21 February 2019 / Published online: 2 March 2019

(c) Springer-Verlag GmbH Germany, part of Springer Nature 2019

\begin{abstract}
Between the initial colonization of North America and the European settlement period, Indigenous American land use practices shaped North American landscapes and ecosystems, but a critical question is the extent of these impacts on the land, and how these influenced the distributions of the flora and fauna. The present study addresses this question by estimating the spatial correlation between continental-scale records of fossil pollen and archaeological radiocarbon data, and provides a detailed analysis of the spatiotemporal relationship between palaeo-populations and ten important North American pollen taxa. Maps of Indigenous American population density, based on the Canadian Archaeological Radiocarbon Database, are compared to maps of plant abundance as estimated by pollen records from the Neotoma Paleoecology Database, using nonparametric kernel estimators and cross-correlation techniques. Periods of high spatial cross-correlation (either positive or negative) between population density and plant abundance were identified, but these associations were intermittent and did not increase towards the present. In many cases, high values of population density corresponded with high values of a particular taxon in one region, but simultaneously corresponded with low values in other regions, lessening the overall correlation between the two fields. This analysis suggests that human impacts were not significant enough to be identified at a continental scale, either due to low population numbers or land use, implying significant impacts of ancient human activities on the vegetation were regional rather than continental.
\end{abstract}

Keywords Anthropocene $\cdot$ Forest history $\cdot$ Spatio-temporal cross-correlation $\cdot$ Kernel smoother $\cdot$ Canadian Archaeological Radiocarbon Database $\cdot$ Neotoma Paleoecology Database

\section{Introduction}

Environmental changes over the past $15 \mathrm{ka}(15,000$ years) in North America have been associated with cultural development and population growth and used to interpret the

Communicated by K. Brown.

Electronic supplementary material The online version of this article (https://doi.org/10.1007/s00334-019-00721-w) contains supplementary material, which is available to authorized users.

Konrad Gajewski

gajewski@uottawa.ca

1 Laboratory for Paleoclimatology and Climatology, Department of Geography, Environment and Geomatics, University of Ottawa, Ottawa, ON K1N6N5, Canada

2 Institute of Stochastics, Ulm University, 89069 Ulm, Germany

3 Department of Mathematics and Statistics, University of Ottawa, Ottawa, ON K1N6N5, Canada archaeological record of technological change. Sociocultural and technological transitions have been explained as a response to challenges and stresses resulting from climate changes (e.g. Fagan 2008; Foster 2012; Kehoe 2017) and early- to mid-Holocene cultural transitions have been correlated with environmental variability on multiple timescales (e.g. Anderson 2001; Kidder 2006). More examples are available from the past 2,000 years; for example, climate changes during the Medieval Warm Period had impacts across the continent, especially in the west where significant droughts were closely tied to cultural changes (e.g. Jones et al. 1999; Foster 2012; Arnold and Martin 2014; Schwindt et al. 2016; Comstock and Cook 2018). The impacts of climate changes hypothesized to have affected the regional archaeological record have been documented (Fiedel 2001; McWeeney and Kellogg 2001), where the palaeoclimate reconstructions were frequently derived from global-scale palaeoclimate syntheses. Indeed, many of the correlations are to ice core and ocean records or other non-local sources of palaeoclimate information. Recently, using radiocarbon 
databases as indicators of demographic changes, regional scale associations between climate changes and population size have been shown (e.g. Munoz et al. 2010; Grayson 2011; Kelly et al. 2013).

At the same time, there is in interest in understanding how human activity may have affected the environment. Historic human impacts on the vegetation in North America are well-understood. European colonists deforested large areas of North America by the early 20th century, although the vegetation has since regrown in many regions (e.g. Cronon 1983; Williams 1989; Whitney 1994; Dyer 2006), and these changes have been observed in fossil pollen studies (e.g. McAndrews 1988; Kujawa et al. 2016). What is less easily determined is the broad-scale impact of Indigenous American land use practices. Through much of the 20th century it was generally assumed that the human footprint in North America prior to European colonization was insignificant. Changes in human population numbers would have been primarily driven by intrinsic factors and influenced by climate and environmental changes (e.g. Munoz et al. 2010; Foster 2012; Kelly et al. 2013). This view assumed that the total population in the Americas was relatively small and the impacts on the environment were minimal, or at best widely scattered (Denevan 1992). Some authors have suggested between 2 and 18 million people may have occupied North America during this time, although these numbers are controversial and questioned (Denevan 1992; Warrick 2008; Peros et al. 2010).

An alternative viewpoint based largely on archaeological and ethnohistoric research is that the population in 1492 CE was very high, particularly in coastal regions and temperate areas, and that human impacts were extensive across many regions in North America (Denevan 1992; Doolittle 2000). Environmental historians have noted reports by the first European settlers of open forests, of burning by Indigenous Americans to encourage game browse and facilitate travel, and of active or abandoned agricultural fields (e.g. Cronon 1983; Silver 1990; Krech 2000; Kay and Simmons 2002; McShea and Healy 2002; Harkin and Lewis 2007). These reports have been extrapolated to suggest that much of the landscape was open woodland, although the extent is questioned (Russell 1983; Abrams and Nowacki 2008). Ethnographic studies have documented the impacts of activities such as the burning of the prairies or forests (e.g. Stewart 2002; Courtwright 2011). Abrams and Nowacki (2008) summarized studies of land survey records and concluded "... that the vast majority of vegetation in the eastern USA was managed directly or indirectly by Native Americans, especially through the use of fire" ( $\mathrm{p} 1134)$. Similar conclusions have been made by many others, and this viewpoint is becoming increasingly accepted (e.g. Pyne 1982; Cronon 1983; Silver 1990; Krech 2000; Kay and Simmons 2002; Stewart 2002; Harkin and Lewis 2007; Courtwright
2011). Collectively, these studies suggest that the eastern North American landscape was a cultural or humanized landscape millennia before 1492 CE (Zelinsky 1973; Orme 1981; Whitehead and Sheehan 1985; Delcourt 1987; Delcourt and Delcourt 1987, 2004; Silver 1990; Butzer 1992; Doolittle 1992; Kay 1994; Krech 2000; Harkin and Lewis 2007; Abrams and Nowacki 2008; Munoz et al. 2010; Courtwright 2011; Denevan 2011). The critical issue now is the quantification of the extent of these impacts regardless of whether they were deliberate (e.g. setting fires, agriculture and silviculture) or incidental (e.g. successional growth, changes in forest composition, extinctions).

In eastern United States, human-set fires may have encouraged the growth of pioneer and disturbance species such as Pinus, Quercus and Populus (Bonnicksen 2000) or thinned out closed forests. Several authors have suggested that Palaeoindian (10.5-9.5 ka) fire use may have been a key driver of past changes in vegetation and fire regime, particularly in biotas not prone to burning (e.g. Marlon et al. 2013). The use of fires continued and intensified into the Archaic period ( 10.0 to $3.0 \mathrm{ka}$ ) when Indigenous Americans began using a more diverse group of foods that included game, fish and a wide variety of plants, and burning larger patches of land to encourage the growth of seed, nut and berryproducing species (Fowler and Konopik 2007). During the Woodland ( 3.0 to $1.0 \mathrm{ka})$ and Mississippian (1.3-0.5 ka) periods, North American cultures in the Midwest and the East focused on building permanent settlements, plant cultivation and domestication (Fowler and Konopik 2007).

Thus, the environmental impacts of human activities over the course of the Holocene may have been significant. For example, Ruddiman $(2003,2014)$ suggested that the demographic collapse of the Indigenous population associated with European colonization coincided with the most significant decrease in $\mathrm{CO}_{2}$ and $\mathrm{CH}_{4}$ in the last 2,000 and 1,000 years, respectively, showing a close association between Indigenous American land use and the global carbon cycle during the last several millennia. Indigenous American fire use could have doubled the number of fires that would have occurred as a result of lightning strikes (Bonnicksen 2000). Atmospheric greenhouse gas levels may have decreased in response to the near cessation of human-induced biomass burning and the regeneration of forests following this population decline (Ruddiman 2003; Ferretti et al. 2005; Faust et al. 2006; Abrams and Nowacki 2008; Nevle et al. 2011; Ruddiman et al. 2011), which may have amplified the global effects of the Little Ice Age (1450-1850 CE; Dull et al. 2010; Koch et al. 2019).

Alternatively, it is possible that population densities in North America may have been too low to have global implications (Ubelaker 1992; Steckle and Rose 2005; Liebmann et al. 2016) and past changes in atmospheric gas levels were not directly influenced by Indigenous American land use 
(Bird et al. 2017). More generally, lower population numbers, perhaps combined with careful management of the landscape, could have meant that Indigenous Americans left a small footprint with only regional or local impact (e.g. Vale 2002; Munoz et al. 2014). Continental-scale palaeoecological research has emphasized the importance of climate variability on vegetation composition (e.g. Williams et al. 2004). On the other hand, palaeoenvironmental studies at local or regional scales have shown strong associations of tree species composition with human activity in time and space, although the intensity of activity has been hard to estimate (e.g. Burden et al. 1986; Delcourt et al. 1986; McAndrews and Boyko-Diakonow 1989; Clark and Royall 1995; Fuller et al. 1998; Parshall and Foster 2002; McLauchlan 2003; Delcourt and Delcourt 2004; Faison et al. 2006; Munoz and Gajewski 2010). Studies of the vegetation of mountainous western North America concluded that human impact, including the setting of fires, was more local than regional (reviewed in Boyd 1999; Vale 2002; Lepofsky and Lertzman 2008), as did a study of the eastern deciduous forest (Munoz et al. 2014). Especially in the west, there is difficulty in separating climate-induced vegetation change from human impacts, given the topographic and ecosystem complexity in the mountain region, such that the spatial extent of the human impact is not clear (e.g. Boyd 1999; Lepofsky and Lertzman 2008). There is a need to understand traditional resource and environmental management (Lepofsky and Armstrong 2018), which to date has been approached through ethnographic and archaeological analysis, and most studies have concluded that impacts are local.

Quantitative estimates of population density are needed to investigate the extent of human impacts on the environment over the Holocene for North America (Day 1953), as well as to better understand how environmental changes may have caused a cultural response. Recently, these data have become available as a result of analyses using the Canadian Archaeological Radiocarbon Database (CARD; Gajewski et al. 2011; Chaput et al. 2015; Martindale et al. 2016). Although archaeological data provide only relative numbers, they have been used, for example, in a reconstruction of the time evolution of the population of North America for the past 15,000 years (Peros et al. 2008)(Fig. 1). These palaeodemographic estimates have also been mapped, depicting the time-space evolution of relative population density (Chaput et al. 2015). Fossil pollen data from sediment cores spanning the continent are available as part of the Neotoma Paleoecology Database (Williams et al. 2018), and it has been demonstrated that these are a proxy for past plant abundance (e.g. Davis 1981; Jacobson et al. 1987; Webb 1988; Webb et al. 1993; Williams et al. 2004). The availability of these databases provides an opportunity to study the question of the interaction of environmental change and human activity (Naudinot and Kelly 2017).
We approach the question of large-scale human-vegetation interactions by comparing estimates of Indigenous American populations over the past $13 \mathrm{ka}$ (Chaput et al. 2015) to data on the distribution of trees during the same time period. We ask two alternative, although related questions. First, did changes in the vegetation affect human activity, including population growth? If tree populations that supported wildlife and produced consumables for Indigenous Americans, such as Quercus or Castanea (e.g. Wang et al. 2013) became more abundant, this could mean a more reliable food source, encouraging larger populations. For example, in the Pacific Northwest, Hebda and Mathewes (1984) have associated the development of large houses and wood use such as canoes with the arrival into the northwest of Thuja plicata, which was a preferred wood for these structures. Kelly et al. (2013) showed an association of population growth and climate variability in Wyoming over the Holocene using the kinds of data we use here. Alternatively, did Indigenous Americans and their activities affect the vegetation in a quantitative, measurable way at regional to continental scales? For example, if Indigenous Americans planted or encouraged the growth of particular tree species, such as Carya or Juglans (Wycoff 1991; Abrams and Nowacki 2008), then the abundance of these trees should increase after a population increase, if numbers are large enough. If there had been extensive burning or clearing through agriculture, as occurred in eastern North America, this should appear as an increase in disturbance taxa such as Populus or Poaceae, or a decrease in late successional taxa such as Acer or Fagus, as seen on a regional scale in Ontario in the late Holocene (Munoz and Gajewski 2010).

Kriesche et al. (unpublished) described a methodology developed for this purpose, and briefly discussed the example of Quercus. In this study, as a next step, we apply this methodology and investigate the large-scale spatial associations in the North American archaeological and pollen records. These results are necessary before complete explanations of the regional intensities of human populationenvironment interactions, requiring case-specific models and accounting for changes in the associations over time, can be conceived (e.g. Anderson 2001).

\section{Methods}

\section{Data}

For estimates of past vegetation, we used pollen data from the Neotoma Paleoecology Database (http://www.neoto madb.org); all North American data were extracted. Because there are very few data from Mexico in the databases, we use North America in this paper to refer to the United States and Canada only. In total, there were 1,151 sites available 
Fig. 1 a Map of the major biomes of North America (Olson et al. 2001) with locations of pollen records extracted from the Neotoma Paleoecology Database (http://www. neotomadb.org). Each point is one multivariate time series of pollen percentages (vegetation) at that site. Note that the record may vary in length. b Map of the major cultural regions of North America (Mooney 1928) with points from the CARD database (Gajewski et al. 2011; Martindale et al. 2016; http:// www.canadianarchaeology.ca). Each point is one radiocarbon date from an archaeological site. Note there may be many points stacked at any location. c Mean July temperature anomaly of North America derived from the pollen records in a (Viau et al. 2006). This curve shows the complete record for the past $14 \mathrm{ka}$. d The same temperature data as in $\mathbf{c}$ but truncated at $10 \mathrm{ka}$ and expanded to better show the variability in the Holocene. This is plotted against taphonomically-corrected human population (black curve) of North America for the past $14 \mathrm{ka}$, estimated using the data from b; see Peros et al. (2010) for details
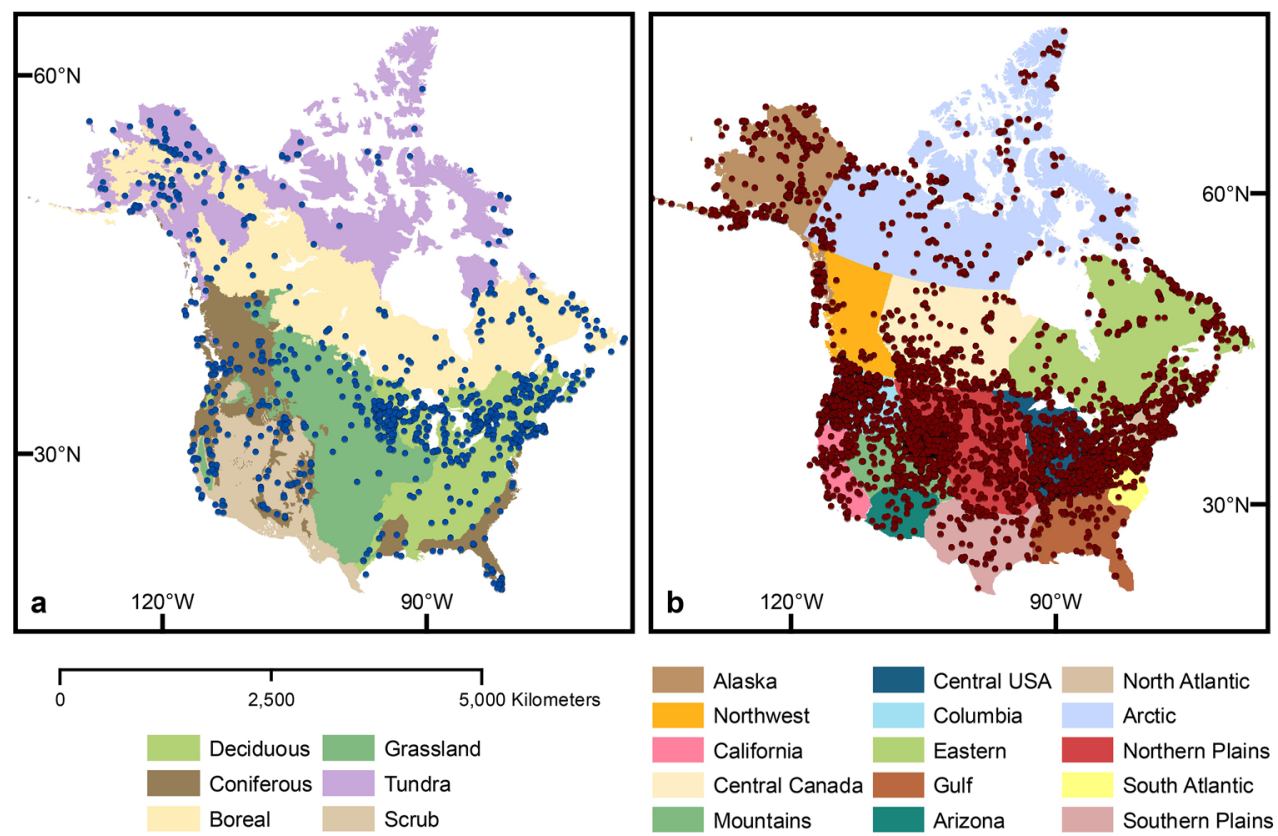

C

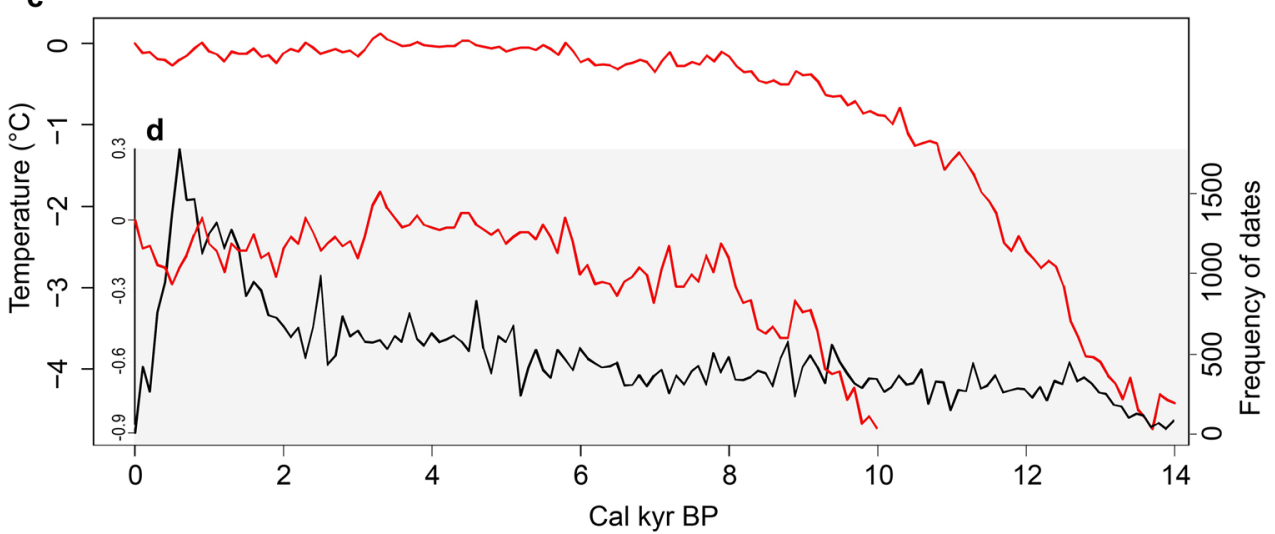

from across North America, although their distribution was uneven (Fig. 1a). The Great Lakes region and eastern North America are particularly well sampled, and sample density decreases to the southwest and far north. Chronology development was discussed in Kriesche et al. (unpublished). Sites vary greatly in temporal resolution of pollen samples and in number of radiocarbon dates, but are nevertheless appropriate for use in this study as shown in previous continentalscale studies at centennial to millennial-scale resolution (e.g. Williams et al. 2004; Viau et al. 2006; Gajewski 2008; Fig. 1c, d).

The pollen sum was based on 64 taxa (Williams and Shuman 2008) and ten were retained for analysis. Taxa were chosen for several reasons, but a first criterion was that they were abundant enough and found across a wide enough range to enable spatial analysis. Boreal and widespread taxa (Picea, Pinus) were included as indicators of late glacial and early Holocene environmental changes (Williams et al. 2004) and also due to interest in human-environment interactions in Beringia (Mason et al. 2001), although we may expect little association with human populations which were at low density at those times (Peros et al. 2010; Chaput et al. 2015). These taxa were also chosen to verify our methodology, since they have previously been mapped on several occasions (discussed below). Several taxa represent major genera of the eastern deciduous forests (Quercus, Castanea; Abrams 1992) or important food sources from that region (Carya, Juglans) and were retained due to the associations that have been suggested in the literature (Wycoff 1991; Abrams and Nowacki 2008; Lepofsky and Armstrong 2018). Important trees of closed stands of the eastern deciduous forest (Acer, Fagus) were included as regional studies have indicated close associations of population and vegetation in the region coincident with their range (Munoz et al. 2010). Finally, two widespread taxa, Populus and Poaceae, were analyzed. Although the many species of Populus have different ranges and functional roles, Peros et al. (2008) have shown that the pollen record can be interpreted as an 
indicator of continental-scale disturbance. Poaceae pollen could indicate possible burning along the prairie-forest border (Stewart 2002; Courtwright 2011), as well as disturbance by fire in forested regions of the east. The taxon selection is therefore biased towards eastern and northern forest regions for this first study, but these are also areas where our site density is greater, and where we could compare our results to previous mapping studies (e.g. Williams et al. 2004).

We used estimates of human population in space and time (Chaput et al. 2015) based on the CARD database (Fig. 1b, c; Gajewski et al. 2011; Martindale et al. 2016; http://www. canadianarchaeology.ca). This consists of over 29,000 radiocarbon dates from archaeological sites distributed across North America. All radiocarbon ages from the pollen and demographic databases were comparably calibrated (Chaput et al. 2015; Kriesche et al. unpublished), and ages are discussed in ka (1,000 years before present). Details of data extraction and preparation of the maps and figures are explained in Chaput et al. (2015, population) and Kriesche et al. (unpublished, pollen).

\section{Methods}

\section{Population}

Chaput et al. (2015) showed the spatial distribution of the human population of North America through time in a series of maps based on a 500-year time-spans, with subsequent maps produced at overlapping intervals of 100 years: 0.5-1.0 ka, 0.6-1.1 ka, .., 12.5-13.0 ka. These maps, interpreted as estimates of past population density, were prepared from the radiocarbon dates using a kernel density estimator, which accounts for biases from inhomogeneous sampling strategies, taphonomic loss and boundary effects. This resulted in a total of 121 maps of population density.

\section{Vegetation}

A series of 121 maps showing the pollen percentage distributions was prepared for each taxon. As with population, an estimator from kernel regression (Kriesche et al. unpublished) was used to determine the spatial distribution of pollen percentages at the central age of each 500-year time period. To enable comparability, the same configurations of the estimators were used as for population, except that the population was illustrated on a logarithmic scale and the pollen percentages on a linear scale. For each time period, the range of the taxon was used as a mask, and population values extracted from within this range. The range at a given year was that region where pollen percentages exceeded 0.2 times the maximum of pollen percentages. As a consequence, the analyses for several taxa are restricted to eastern North America. These estimated values were used for correlation analyses.

\section{Correlations and cross-correlations}

Spatial correlation functions of both population and pollen percentage maps (separately) were estimated for each time period. All of the 121 correlation functions for population and for each taxon within the range were summarized in one graph, a heat map that shows the spatial autocorrelation of population or the taxon through time. Spatial crosscorrelation functions were then computed showing the relationship between estimates of population and pollen abundance of each taxon, restricted to the estimated taxon range. The series of 121 functions for each taxon were summarized in one plot, which identify times of strong spatial cross-correlation between population and taxa.

To determine if changes in population and taxon abundance were correlated, difference maps were produced subtracting maps with a temporal distance of 500 years to provide 116 maps of 500-year changes in population and taxon abundance (in 100-year steps). These correspond to the same 500-year change interval and also to intervals that are shifted by the temporal lags $+100,+200$, $\ldots,+1,000$ years, and $-100,-200, \ldots,-1,000$ years. A positive lag means that vegetation change follows a change in population and a negative lag means the opposite. Similarly to the actual maps, spatial correlation functions were estimated for the difference maps of vegetation abundance and population for each 500-year change interval, and summarized as heat maps. Cross-correlations between the difference maps for vegetation abundance and population were also prepared for lags of $-1,000,-900, \ldots,-100,0$, $100, \ldots, 900,1,000$ years and the comparable summaries for all time periods are shown as heat maps.

The final result depicts the mean cross-correlations between differences in taxon abundance and population at small distances (between 30 and $200 \mathrm{~km}$ ), summarized in a matrix plot. These summarize all estimated statistical cross-correlations between changes in the considered taxon and population (for all temporal lags) in one graph (Fig. 2).

Nonparametric resampling methods were used to assess the significance of the obtained correlation results (Kriesche et al. unpublished). Correlations with higher absolute values are considered to indicate a real signal: ca. 0.15 (Picea, Pinus), 0.2 (Acer, Carya, Juglans), 0.25 (Fagus), 0.3 (Castanea, Poaceae, Quercus) and 0.4 (Populus). A more detailed methodology including an illustration of each step mentioned above can be found in Kriesche et al. (unpublished) and in ESM Appendix S1. 
Fig. 2 Diagrams summarizing the cross-correlations between differences maps of taxon abundance and population density. For each of the spatial cross-correlation functions (121 for each taxon), the average correlation for distances between 30 and $200 \mathrm{~km}$ was extracted, for zero lag, \pm 100 years, \pm 200 years, $\ldots, \pm 1,000$ years, and these plotted on the one diagram. A positive lag means that vegetation change corresponds to a more recent 500-year change interval than change in population and a negative lag means the opposite
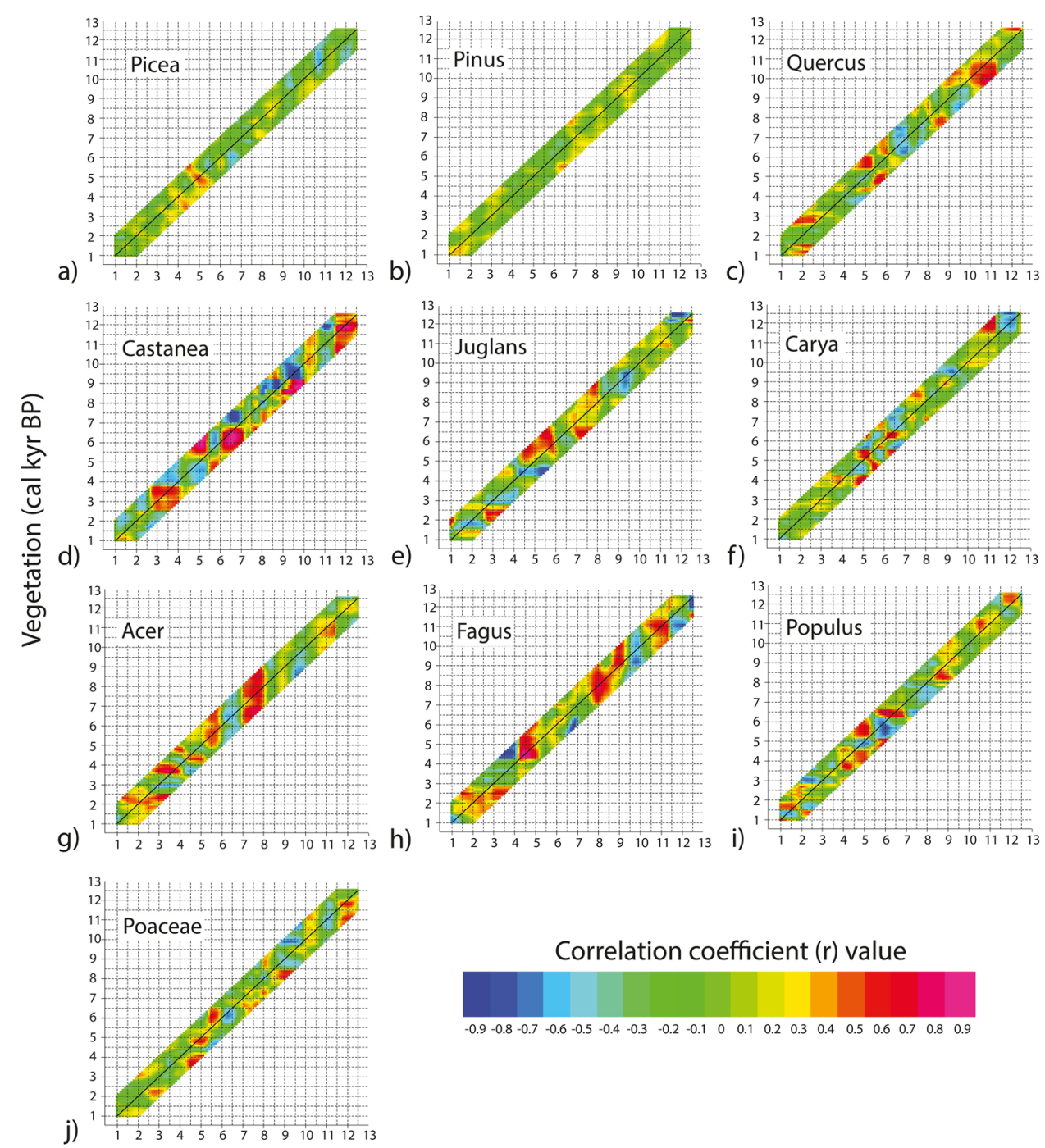

h)

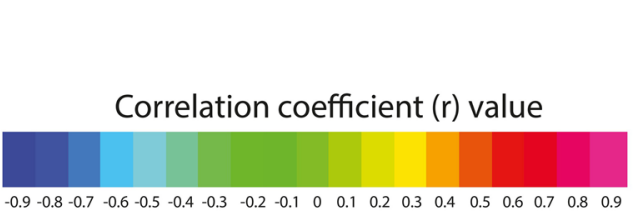

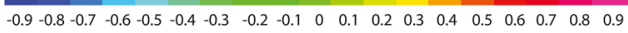

Population (cal kyr BP)

\section{Results}

\section{Population}

The population maps were discussed in detail in Chaput et al. (2015). Prior to $10 \mathrm{ka}$, there were population maxima in the southern United States and northwestern North America. Maxima remained in the south in the early Holocene, and population tended to increase in the west over the course of the Holocene. Population increased across all of North America in the past $2 \mathrm{ka}$. Our maps do not extend into the European contact period as they are based on radiocarbon dates which tend to be used less when historical information is available to date deposits. They therefore do not record the large Indigenous population decrease at that time.

\section{Boreal and widespread taxa: Picea and Pinus}

The range and abundance maps depicting the distribution of Picea through time closely resemble those presented in Williams et al. (2004), suggesting that the differences in methodology are not greatly influencing the results. There were no clear associations with population or changes in population and these taxa. In the early Holocene ( $>\sim 8 \mathrm{ka}$ ), large increases in Picea occurred in the northwestern part of range, but there were both positive and negative changes in population density depending on the region, reducing the cross-correlation of the difference maps of Picea and population (Fig. 2a). In general, zones of increasing or decreasing values were sometimes in phase or not with population (ESM Appendix S2), so the cross-correlation of Picea with population was low. During the period between $\sim 5.5$ 
to $3.5 \mathrm{ka}$ both Picea and population increased in the east, leading to a brief period of high positive cross-correlations (ESM Appendix S3). In the past $1 \mathrm{ka}$, changes in Picea were relatively small, whereas population was increasing across the entire range; the cross-correlation of the change maps remained non-significant as a consequence. Again, our migration maps for Pinus look similar to those of Williams et al. (2004) and there are no clear correlations with population change maps (Fig. 2b). Occasional associations between population and Pinus in the southern, eastern or western regions are masked by a lack of association in others.

\section{Major taxa of the eastern deciduous forest: Quercus and Castanea}

Quercus was discussed in Kriesche et al. (unpublished) as an example of application of the methodology. At $12 \mathrm{ka}$ there was abundant Quercus in the Gulf States, and by the mid-Holocene it was found across the present-day range, with a maximum from Illinois to Virginia. There was some association between Quercus and population (Fig. 2c), probably because Quercus is representative of the deciduous forest rather than through any kind of causal relation between Quercus and population.

High values of the spatial autocorrelation and crosscorrelation of population and Castanea prior to $\sim 5 \mathrm{ka}$ are difficult to interpret as the pollen record is dominated by sites in Texas (Bryant and Holloway 1985), resulting in a discontinuous range (ESM Appendix S2). The cross-correlation between Castanea and population density is relatively high and positive in the late Holocene (most recent $~ 4 \mathrm{ka}$ ), as both variables have high values in the central portion of the range (Fig. 2d). In the past $2 \mathrm{ka}$, population maxima were found in the western portion of the range, reducing the cross-correlation (ESM Appendix S3). Castanea is one taxon where the positive and negative lag correlations differed (Fig. 2d), but this is mostly prior to $7 \mathrm{ka}$. Between $5 \mathrm{ka}$ and $4 \mathrm{ka}$, the range of Castanea decreased as it moved northward, whereas population was increasing. Between 3.5 and $2.5 \mathrm{ka}$, both pollen and population increased, especially in the southern part of the range. During the past $2 \mathrm{ka}$, the Castanea range changed little, except in the north (Paillet 2002) where it increased, whereas population was increasing across the range, so there was little cross-correlation.

\section{Major mast trees of the eastern deciduous forest: Juglans and Carya}

Shortly after $12 \mathrm{ka}$, the range of Juglans was located in a broad area from Louisiana to the Great lakes, west of the Appalachians (ESM Appendix S2). By 9-10 ka, Juglans decreased in the south, so the range was at a minimum. Maximum pollen percentages were centred over the Midwest and remained in this area until the present. In the early Holocene, the cross-correlation of Juglans with population was relatively small, since the maximum population relative density was in the south, whereas maximum Juglans was in the central part of the eastern United States (Fig. 2e). Similarly, the difference maps showed a complex sequence of changes that were rarely aligned between population density and Juglans pollen percentages. Through most of the mid- to late Holocene, the range of Juglans changed little, and the population maxima were to the south and east of that of Juglans. Since the trees seemed to increase first, this does not suggest that Indigenous populations caused an increase in abundance in this species, although the association may suggest that it was exploited. In the late Holocene, population increased across the entire range of Juglans, and maximum values were overlapping with the pollen maximum, displaced to the west. High values of population associated with high and low values of Juglans contributed to the lower spatial autocorrelation. This preceded the major increase in agriculture in the region.

The range of Carya gradually extended northward in the early Holocene, especially west of Appalachians, and extending to the Great Lakes by 9 ka (ESM Appendix S2). As Carya moved northward and was found at moderate values across a large range, the maximum in population density was also broadly coincident (ESM Appendix S3), leading to high cross-correlations between 10 and $7.5 \mathrm{ka}$ (Fig. 2f). In the mid-Holocene ( $~ 8$ to $4 \mathrm{ka}$ ), high values of population sometimes corresponded to high values of Carya, but in other regions to low values, so the overall spatial correlation was around zero. The spatial cross-correlations of the difference maps showed few consistent associations in the early or late Holocene (Fig. 2f). An alternation of positive and negative cross-correlations in the mid-Holocene was driven in part by very large increases in Carya from 7 to $5 \mathrm{ka}$ in Texas, which were accompanied with increases or decreases in population. Carya decreased in abundance in the southern part of the range at times when population did as well, leading to some periods of high cross-correlation. Between 4.5 and $3.5 \mathrm{ka}$, Carya increased in the north-central part of the range, and large population increases in the same area contributed to the band of high correlation in Fig. 2f. In the past $2 \mathrm{ka}$, Carya changed less in the northern part of the range while at times decreasing in Texas; during this time population was greatly increasing in the central portion of the range, leading to overall low cross-correlations.

\section{Northern deciduous forest: Fagus and Acer}

Acer and Fagus were found in the northern part of the eastern deciduous forest in the mid- to late Holocene (ESM Appendix S2). At $13 \mathrm{ka}$, the range of Acer was extensive, with maximum values in south-central United States. Acer 
moved north quickly, present even up to the retreating ice sheet. By the mid-Holocene until the present, maximum values were centred on Ontario. The stability of the range in the mid- to late Holocene, and general increase in abundance led to relatively high cross-correlations with population at certain times, but population maxima also shifted, leading to alternating periods of positive and negative correlation (Fig. 2g; ESM Appendix S3). For example, in the mid-Holocene, there was a minimum in population density in the area centred over Ontario where Acer was most abundant, leading to weak cross-correlations. Generally, the maximum in population was found to the south of the region of most abundant Acer. The period of large positive cross-correlations in the difference maps from 8 to $9 \mathrm{ka}$ (Acer) and 7-8 ka (population) occurred when Acer was increasing greatly in Ontario, and population was relatively constant across all of its range. In the past $2 \mathrm{ka}$, Acer increased in the southwest portion of its range, when population was also increasing, leading to positive correlation. Given the stability of a large maximum in Acer centred over southern Ontario through much of the Holocene in both the absolute and difference maps, the lack of a comparable feature in population density (in either a negative or positive sense) reduces the correlation between these two variables.

By $10 \mathrm{ka}$ there were high values of Fagus in western Pennsylvania; this remained until the present. In the past $8.5 \mathrm{ka}$, large values of Fagus pollen were restricted to the north of Virginia, with most abundant values in Pennsylvania and New York. In the oldest part of the record, when Fagus was restricted to the south, there was little association of Fagus and population density, and this continued in the period between 11 and $8.5 \mathrm{ka}$ as it migrated rapidly northward (Fig. 2h). In the period around 8 ka, Fagus difference maps were positive, centred on the range for long time periods, whereas population increased or decreased in various portions of the range. Large positive values of cross-correlation occurred with large increases in Fagus and small but smooth values of population density. The large positive association between 4.5 and $6 \mathrm{ka}$ (Fagus) and 4-5 ka (population) occurred when both were increasing in the northeastern portion of the range. After 4 ka, Fagus increased in Ontario and Quebec, at times when population was decreasing and at other times when increasing. Increases in Fagus and population in the past $3 \mathrm{ka}$ in the western part of the range led to positive cross-correlations.

\section{Disturbance and prairie indicators: Populus and Poaceae}

The range of significant values of Populus decreased rapidly between 10 and $8 \mathrm{ka}$, and almost no pollen was found in sediments subsequently (Peros et al. 2008, ESM Appendix S2). Cross-correlations of Populus and population were high in the early Holocene, as both were abundant in Beringia and Alberta (Fig. 2i, ESM Appendix S3). After 8 ka, when the range of Populus was very small and broken into disjunct regions, the autocorrelation functions decreased substantially, as did the cross-correlation with population. In the mid-Holocene, during periods of strong cross-correlation of the difference maps, Populus was restricted to a small area of the Southwestern US.

Before $9 \mathrm{ka}$, Poaceae pollen was found in several areas from the Arctic to Florida. Over the course of the Holocene, it increased in abundance in the present-day prairie region, as this biome developed after $8 \mathrm{ka}$. High values of Poaceae and population, especially in the southern plains, and low values elsewhere led to high spatial cross-correlations between 6.5 and $3.5 \mathrm{ka}$ (Fig. 2j). The cross-correlation of the maps as well as the differences decreased after $5 \mathrm{ka}$, as maximum Poaceae values were found in the central portion of the range, whereas the maximum population was around the edges of the range.

\section{Discussion}

Periods of high spatial cross-correlation between population density and pollen abundance were identified, although they were limited in extent in time and space. However, the correlations did not consistently increase across all taxa, although there was a large increase in population in the late Holocene, and the plants had mostly become established in their respective ranges. Frequently, maxima in population and a plant taxon were displaced, which may be associated with site density and the estimation of the intensity surfaces, but is more likely due to a limited association between population density and abundance of the plant taxon. This suggests that the associations are sub-regional in extent. The clear associations between population density and environmental change seen at a regional scale (e.g. Munoz et al. 2010; Kelly et al. 2013) do not appear to scale up to the continent either because spatial differences lower overall correlations, or impacts always remain regional. These results justify the need for regional-scale studies, such as Munoz et al. (2010) and Kelly et al. (2013), to identify and quantify human-environment associations.

We do not see evidence of the converse: biome-scale impacts of human activity on the vegetation, as hypothesized by numerous authors (see Introduction), especially for eastern United States. We should expect increasing crosscorrelations in the recent past with increasing populations (Peros et al. 2008) and expansion of agriculture in the eastern deciduous forest, but in fact, this was not observed. If extensive human-caused fires did push the forests of eastern North America toward more Quercus and other disturbance taxa across a large area, we would not expect high positive 
correlations with Acer and Fagus. Given the importance of mast species as a food source, we would have expected a higher correlation of Juglans and Carya with population than was seen. The increase of Populus, as agriculture developed in Ontario (Munoz and Gajewski 2010), does not seem to scale upwards to the biome scale. Several possibilities can be proposed as explanation for this lack of association.

a. Associations were minimal: human impact was not great enough to have a significant influence on the vegetation, either due to low human population density or the intensity of the activities. Our conclusion is that there is presently little indication of continental-scale impacts of human activities on the vegetation of North America over the course of the Holocene, but rather that it was local and regional. Vale (2002) provided a classification of land use by Indigenous Americans useful for this discussion, and more work at regional scales, as discussed in the Introduction, could document this interaction.

b. Alternatively, the impact of Indigenous American activity on the vegetation may have been widespread, but not associated with changes in the human population density. Although this is a possibility, it cannot be investigated at present. Ongoing work attempting to estimate vegetation density (Chaput and Gajewski 2018), and new data on charcoal and pollen from more sites may help resolve this question.

c. We did not see the associations since our method is too insensitive, or results are highly determined by aspects of the data such as a low signal-to-noise ratio. We identified some taxa, especially those that are underrepresented in the pollen rain, where problems with estimating the spatial fields for part of the time period may make interpretation more difficult. Inadequacies with the databases, especially low site density or incomplete archaeological data in some regions may be reducing the sensitivity of the study. However, for many taxa and time periods, the maps resemble previous versions (Davis 1981; Jacobson et al. 1987; Webb 1988; Webb et al. 1993; Williams et al. 2004) and associations should be observable. The population maps are consistent with archaeological knowledge (Chaput et al. 2015). Future work at regional scales, or using different averaging periods, could determine the robustness of these results.

Overall, there was little relation between changes in Picea or Pinus and changes in population. This is not surprising, as even in the recent past, the human population density of boreal regions was low and agriculture was not possible. In the mountains of the west, the density of available pollen records is still relatively low, given the topographic and ecological complexity of the region, and thus it is difficult to find associations. The wide range of these taxa, extending over many different cultures and climates can lead to regional positive and negative correlations between population density and the taxon cancelling and leaving little correlation. We also saw little relation between Populus and population. Although local and regional palaeoecological studies have shown the impact of agriculture on longterm vegetation dynamics (Delcourt 1987; McAndrews and Boyko-Diakonow 1989; Clark and Royall 1995; Delcourt and Delcourt 2004; Munoz and Gajewski 2010), these impacts apparently do not scale to the entire forest region.

It is widely claimed that the prairie or especially the prairie-forest border was maintained by fires (e.g. Gleason 1913; Pyne 1982, 2007; Abrams 1992; Courtwright 2011) and that these were augmented, if not almost entirely caused, by humans. Again, we could not identify a clear association of population with the extent of the prairie, as shown by the range of Poaceae pollen, and more work is needed to understand the human role in prairie fires.

In the eastern deciduous forest, we have the most data, an extensive historical literature and several regions of extensive palaeoecological study on the interaction of Indigenous populations with the environment (Delcourt and Delcourt 1979; Delcourt et al. 1986; Delcourt 1987; Foster et al. 2002; Munoz and Gajewski 2010). The importance of human-caused fires has been emphasized by many authors but whether or not the pre-European eastern forests were continuous or open parklands is not resolved (Pyne 1982; Cronon 1983; Silver 1990; Krech 2000; Kay and Simmons 2002; Stewart 2002; Harkin and Lewis 2007; Abrams and Nowacki 2008; Courtwright 2011). The continual clearing of land, abandoning and moving to new locations, especially after the introduction of maize, could have had a significant impact on the vegetation, especially if fire was used to aid in clearing the forests, although Doolittle (1992) has questioned some of the assumptions about this aspect. We would expect an increase in grasses and other herbaceous plants after the introduction of agriculture, or as a consequence of extensive burning. There are many historical reports of Indigenous American ground fires in the forests of eastern North America and this is supposed to have affected the large-scale nature of the forests (e.g. Silver 1990; Stewart 2002). However, palaeoecological studies find little evidence for fires in the region (e.g. Clark and Royall 1996; Lafontaine-Boyer and Gajewski 2014), although there are few available records. Quercus would be favoured by fires caused by human activity (Abrams 1992; McShea and Healy 2002; Black et al. 2006; Tulowiecki and Larsen 2015), however, we did not see an association. Due to its ability to sprout, Castanea increased after European settlement (Southgate 2006) and there is speculation that it may have been favoured by fires associated with Indigenous American populations in New England (Foster et al. 2002), but we see little evidence in our results. We might expect Acer and Fagus to 
decrease if growth of mast trees were being encouraged by Indigenous American activities such as fire or planting, as these are late successional canopy trees and can reproduce in the shade, whereas positive correlations of these two taxa with population density would be expected if populations were having little impact on the forests. The overall positive association of Fagus and Acer abundances with population may suggest that any human disturbance was insufficient for wide-scale conversion of the forest into earlier successional states, as shown, for example in southern Ontario (Munoz and Gajewski 2010). The alternative interpretation is that factors that favoured the maintenance of these taxa also maintained populations of Indigenous Americans, and this seems to be the nature of the association of population and vegetation in this region.

An extensive literature has noted the importance of acorns and nuts for human consumption as well as for animal populations they would have hunted (e.g. Delcourt and Delcourt 1979; Silver 1990; Wycoff 1991; Anderson 2001; Scarry 2003). There is a possibility of Indigenous American dispersal of nut trees either deliberately or at least more rapidly than would have occurred naturally (Dorney 1981; Wycoff 1991; MacDougall 2003; Smith 2007). There are also reports of large populations of mast-producing trees in association with villages, due to intentional or accidental growth of trees planted or discarded (Silver 1990; Black et al. 2006). Today, Carya is not regenerating across large areas in eastern North America (Cowden et al. 2014). Carya would increase in abundance within the range not only at times of appropriate temperature and moisture, but also with sufficient canopy disturbance, and we may expect an increase when population increased. However, increased drought or other factors could also increase canopy disturbance, and the lack of a clear association with population (Fig. 2f) may indicate a lack of such disturbances. The clearest signal of a potential association between these two taxa and population is found in the northeastern United States in the middle Holocene, and a regional study could help determine its significance.

Studies in Eurasia have suggested increasingly intense impacts of human activity as the Holocene progressed, and in extreme cases, have led to ideas of an "early Anthropocene" (Ruddiman 2014), which proposes that human impacts on the global climate (carbon cycle) began to be measurable thousands of years ago. We attempted to determine if the impacts of Indigenous North Americans contributed to this early Anthropocene. The results of our study do not suggest a significant impact; if they had occurred, we could not identify these at a continental scale. Rather, we identified regional-scale associations between changes in human population density and vegetation change, perhaps due to increasing human adaptation as the forests developed, which led to periods of positive association. Further regional studies may illustrate the complex interactions of humans and their environment on long timescales, and better identify the spatial extent of impacts.

Acknowledgements Pollen data are available from the Neotoma Paleoecology Database (http://www.neotomadb.org), and the palaeo-population data are available from the Canadian Archaeological Radiocarbon Database (http://www.canadianarchaeology.ca). We acknowledge those who contributed data to both databases, as well as database coordinators, especially Eric Grimm, Simon Goring, Andrew Martindale and the late Richard Morlan. This work was funded by the Natural Sciences and Engineering Research Council of Canada (NSERC) and Deutscher Akademischer Austauschdienst (DAAD).

Open Access This article is distributed under the terms of the Creative Commons Attribution 4.0 International License (http://creativeco mmons.org/licenses/by/4.0/), which permits unrestricted use, distribution, and reproduction in any medium, provided you give appropriate credit to the original author(s) and the source, provide a link to the Creative Commons license, and indicate if changes were made.

\section{References}

Abrams MD (1992) Fire and the development of oak forests. Bioscience 42:346-353

Abrams MD, Nowacki GJ (2008) Native Americans as active and passive promoters of mast and fruit trees in the eastern USA. Holocene $18: 1,123-1,137$

Anderson D (2001) Climate and cultural change in prehistoric and early historic eastern North America. Archaeol East North Am 29:143-186

Arnold J, Martin L (2014) Botanical evidence of paleodietary and environmental change: drought on the Channel Islands, California. Am Antiqu 79:227-248

Bird BW, Wilson JJ, Gilhooly WP III, Steinman BA, Stamps L (2017) Midcontinental Native American population dynamics and late Holocene hydroclimate extremes. Sci Rep 7:41628

Black BA, Ruffner CM, Abrams MD (2006) Native American influences on the forest composition of the Allegheny Plateau, northwest Pennsylvania. Can J For Res 36:1,266-1,275

Bonnicksen TM (2000) America's ancient forests: from the ice age to the age of discovery. Wiley, New York

Boyd R (1999) Indians, fire and the land in the Pacific Northwest. Oregon State University Press, Corvallis

Bryant VM Jr, Holloway RG (1985) A Late-Quaternary paleoenvironmental record of Texas: an overview of the pollen evidence. In: Bryant VM Jr, Holloway RG (eds) Pollen records of Late Quaternary North American sediments. American Association of Stratigraphic Palynologists Foundation, Dallas, pp 39-70

Burden ET, McAndrews JH, Norris G (1986) Palynology of Indian and European forest clearance and farming in lake sediment cores from Awenda Provincial Park, Ontario. Can J Earth Sci 23:43-54

Butzer KW (1992) The Americas before and after 1492: an introduction to current geographical research. Ann Assoc Am Geogr 82:345-368

Chaput MA, Gajewski K (2018) Relative pollen productivity estimates and changes in Holocene vegetation cover in the deciduous forest of southeastern Quebec. Canada Botany 96:299-317. https://doi. org/10.1139/cjb-2017-0193

Chaput MA, Kriesche B, Betts M, Martindale A, Kulik R, Schmidt V, Gajewski K (2015) Spatiotemporal distribution of 
Holocene populations in North America. Proc Natl Acad Sci USA 112:12,127-12,132

Clark JS, Royall PD (1995) Transformation of a northern hardwood forest by aboriginal (Iroquois) fire: charcoal evidence from Crawford Lake, Ontario, Canada. Holocene 5:1-9

Clark JS, Royall PD (1996) Local and regional sediment charcoal evidence for fire regimes in presettlement north-eastern North America. J Ecol 84:365-382

Comstock AR, Cook RA (2018) Climate change and migration along a Mississippian periphery: a Fort Ancient example. Am Antiqu 83:91-108

Courtwright J (2011) Prairie fire: a Great Plains history. University Press of Kansas, Lawrence

Cowden MM, Hart JL, Buchanan ML (2014) Canopy accession strategies and climate responses for three Carya species common in the Eastern Deciduous Forest. Trees 28:223-235

Cronon W (1983) Changes in the Land: Indians, colonists and the ecology of New England. Hill \& Wang, New York

Davis MB (1981) Quaternary history and the stability of forest communities. In: West DC, Shugart HH, Botkin DB (eds) Forest succession. Springer, New York, pp 132-153

Day GM (1953) The Indian as an ecological factor in the northeastern forest. Ecology 34:329-346

Delcourt HR (1987) The impact of prehistoric agriculture and land occupation on natural vegetation. Trends Ecol Evol 2:39-44

Delcourt PA, Delcourt HR (1979) Late Pleistocene and Holocene distributional history of the deciduous forest in the Southeastern United States. Veröff Geobot Inst Eidgenöss Tech Hochsch Stift Rübel Zür 68:79-107

Delcourt PA, Delcourt HR (1987) Long-term forest dynamics of the temperate zone. Springer, New York

Delcourt PA, Delcourt HR (2004) Prehistoric Native Americans and ecological change. Cambridge University Press, Cambridge

Delcourt PA, Delcourt HR, Cridlebaugh PA, Chapman J (1986) Holocene ethnobotanical and paleoecological record of human impact on vegetation in the Little Tennessee River Valley, Tennessee. Quat Res 25:330-349

Denevan WM (1992) The pristine myth: the landscape of the Americas in 1492. Ann Am Assoc Geogr 82:369-385

Denevan WM (2011) The "Pristine Myth" revisited. Geogr Rev 101:576-591

Doolittle WE (1992) Agriculture in North America on the eve of contact: a reassessment. Ann Am Assoc Geogr 82:386-401

Doolittle WE (2000) Cultivated landscapes of Native North America. Oxford University Press, Oxford

Dorney JR (1981) The impact of Native Americans on presettlement vegetation in southeastern Wisconsin. Trans Wis Acad Sci Arts Lett 69:26-36

Dull RA, Nevle RJ, Woods WI, Bird DK, Avnery S, Devenan WM (2010) The Columbian Encounter and the Little Ice Age: Abrupt land use change, fire, and greenhouse forcing. Ann Am Assoc Geogr 100:755-771

Dyer JM (2006) Revisiting the deciduous forests of Eastern North America. Bioscience 56:341-352

Fagan B (2008) The great warming: climate change and the rise and fall of civilizations. Bloomsbury, New York

Faison EK, Foster DR, Oswald WW, Hansen BCS, Doughty E (2006) Early Holocene openlands in southern New England. Ecology $87: 2,537-3,547$

Faust FX, Gnecco C, Mannstein H, Stamm J (2006) Evidence for the postconquest demographic collapse of the Americas in historical $\mathrm{CO}_{2}$ levels. Earth Interact 10:1-14

Ferretti DF, Miller JB, White JWC et al (2005) Unexpected changes to the global methane budget over the past 2,000 years. Science 309:1,714-1,717
Fiedel SJ (2001) What happened in the early Woodland? Archaeol East North Am 29:101-142

Foster WC (2012) Climate and culture change in North America AD 900-1600. University of Texas Press, Austin

Foster DR, Clayden S, Orwig DA, Hall B, Barry S (2002) Oak, chestnut and fire: climatic and cultural controls of long-term forest dynamics in New England, USA. J Biogeogr 29:1,359-1379

Fowler C, Konopik E (2007) The history of fire in the southern United States. Hum Ecol Rev 14:165-176

Fuller JL, Foster DR, McLachlan J, Drake N (1998) Impact of human activity on regional forest composition and dynamics in central New England. Ecosystems 1:76-95

Gajewski K (2008) The Global Pollen Database in biogeographical and palaeoclimatic studies. Prog Phys Geogr 32:379-402

Gajewski K, Munoz S, Peros M, Viau A, Morlan R, Betts M (2011) The Canadian Archaeological Radiocarbon Database (CARD): archaeological ${ }^{14} \mathrm{C}$ dates in North America and their paleoenvironmental context. Radiocarbon 53:371-394

Gleason HA (1913) The relation of forest distribution and prairie fires in the Middle West. Torreya 13:173-181

Grayson DK (2011) The Great Basin: a natural prehistory. University of California Press, Berkeley

Harkin ME, Lewis DR (2007) Native Americans and the Environment: perspectives on the Ecological Indian. University of Nebraska Press, Lincoln

Hebda RJ, Mathewes RW (1984) Holocene history of cedar and Native Indian cultures of the North American Pacific Coast. Science 225:711-713

Jacobson GL Jr, Webb T III, Grimm EC (1987) Patterns and rates of vegetation change during the deglaciation of eastern North America. In: Ruddiman WF, Wright HE Jr (eds) North America and adjacent oceans during the last deglaciation. The Geology of North America K-3. Boulder, Colorado, pp 277-288

Jones TL, Brown GM, Raab LM et al (1999) Environmental Imperatives reconsidered: demographic crises in western North America during the Medieval Climate Anomaly. Curr Anthropol 40:137-170

Kay CE (1994) Aboriginal overkill: the role of Native Americans in structuring western ecosystems. Hum Nat 5:359-398

Kay CE, Simmons RT (2002) Wilderness and political ecology. University of Utah Press, Salt Lake City, Utah

Kehoe A (2017) North America before the European invasions. Routledge, New York

Kelly RL, Surovell TA, Shuman BN, Smith GM (2013) A continuous climatic impact on Holocene human population in the Rocky Mountains. Proc Natl Acad Sci USA 110:443-447

Kidder TR (2006) Climate change and the Archaic to Woodland transition (3,000-2,500 cal вP) in the Mississippi River Basin. Am Antiqu 71:195-231

Koch A, Brierley C, Maslin MM, Lewis SL (2019) Earth system impacts of the European arrival and Great Dying in the Americas after 1492. Quat Sci Rev 207:13-36

Krech S III (2000) The Ecological Indian: myth and history. W.W. Norton \& Company, New York

Kujawa ER, Goring S, Dawson A et al (2016) The effects of anthropogenic land cover change on pollen-vegetation relationships in the American Midwest. Anthropocene 15:60-71

Lafontaine-Boyer K, Gajewski K (2014) Vegetation dynamics in relation to late-Holocene climate variability and disturbance, Outaouais Québec, Canada. Holocene 24:1,515-1,526

Lepofsky D, Armstrong CG (2018) Foraging new ground: documenting ancient resource and environmental management in Canadian Archaeology. Can J Archaeol 42:57-73

Lepofsky D, Lertzman K (2008) Documenting ancient plant management in the northwest of North America. Botany 86:129-145 
Liebmann MJ, Farella J, Roos CI, Stack A, Martini S, Swetnam TW (2016) Native American depopulation, reforestation, and fire regimes in the Southwest United States, 1492-1900 CE. Proc Natl Acad Sci USA 113:E696-E704

MacDougall A (2003) Did Native Americans influence the northern migration of plants during the Holocene? J Biogeogr 30:633-647

Marlon JR, Bartlein PJ, Daniau A-L et al (2013) Global biomass burning: a synthesis and review of Holocene paleofire records and their controls. Quat Sci Rev 65:5-25

Martindale A, Morlan R, Betts M et al (2016) Canadian archaeological radiocarbon database (CARD 2.1). http://www.canadianar chaeology.ca

Mason OK, Bowers PM, Hopkins DM (2001) The early Holocene Milankovitch thermal maximum and humans: adverse conditions for the Denali complex of eastern Beringia. Quat Sci Rev 20:525-548

McAndrews JH (1988) Human disturbance of North American forests and grasslands: the fossil pollen record. In: Huntley B, Webb T III (eds) Vegetation history. Handbook of vegetation sciences 7. Kluwer, Utrecht, pp 673-697

McAndrews JH, Boyko-Diakonow M (1989) Pollen analysis of varved sediment at Crawford Lake, Ontario: evidence of Indian and European farming. In: Fulton RJ (ed) Quaternary Geology of Canada and Greenland. Geological Survey of Canada, Geology of Canada Series 1. Geological Survey of Canada, Ottawa, pp 528-530

McLauchlan K (2003) Plant cultivation and forest clearance by prehistoric North Americans: pollen evidence from Fort Ancient. Ohio USA Holocene 13:557-566

McShea WJ, Healy WM (2002) Oak Forest ecosystems: ecology and management for wildlife. The Johns Hopkins University Press, Baltimore

McWeeney L, Kellogg DC (2001) Early and middle Holocene climate changes and settlement patterns along the eastern coast of North America. Archaeol East North Am 29:187-212

Mooney J (1928) The Aboriginal population of America north of Mexico. In: Swanton JR (ed) Smithsonian miscellaneous collections 80, no 7. Smithsonian Institution, Washington

Munoz SE, Gajewski K (2010) Distinguishing prehistoric human influence on late-Holocene forests in southern Ontario, Canada. Holocene 20:967-981

Munoz SE, Gajewski K, Peros MC (2010) Synchronous environmental and cultural change in the prehistory of the north-eastern United States. Proc Natl Acad Sci USA 107:22,008-22,013

Munoz SE, Mladenoff DJ, Schroeder S, Williams JW (2014) Defining the spatial patterns of historical land use associated with indigenous societies of eastern North America. J Biogeogr $41: 2,195-2,210$

Naudinot N, Kelly RL (2017) Climate change and archaeology. Quat Int 428:1-2

Nevle RJ, Bird DK, Ruddiman WF, Dull RA (2011) Neotropical human-landscape interactions, fire, and atmospheric $\mathrm{CO}_{2}$ during European conquest. Holocene 21:853-864

Olson DM, Dinerstein E, Wikramanayake ED et al (2001) Terrestrial ecoregions of the world: a new map of life on Earth. Bioscience 51:933-938

Orme B (1981) Anthropology for archaeologists. Duckworth, London

Paillet FL (2002) Chestnut history and ecology of a transformed species. J Biogeogr 29:1,517-1,530

Parshall T, Foster DR (2002) Fire on the New England landscape: regional and temporal variation, cultural and environmental controls. J Biogeogr 29:1,305-1,317

Peros M, Gajewski K, Viau AE (2008) Continental-scale tree population response to rapid climate change, competition and disturbance. Glob Ecol Biogeogr 17:658-669
Peros MC, Munoz SE, Gajewski K, Viau AE (2010) Prehistoric demography of North America inferred from radiocarbon data. J Archaeol Sci 37:656-664

Pyne SJ (1982) Fire in America. Princeton University Press, Princeton

Pyne SJ (2007) Awful splendor: a fire history of Canada. University of British Columbia Press, British Columbia

Ruddiman WF (2003) The anthropogenic greenhouse era began thousands of years ago. Clim Chang 61:261-293

Ruddiman WF (2014) Earth transformed. Freeman and Company, New York

Ruddiman WF, Kutzbach JE, Vavrus SJ (2011) Can natural or anthropogenic explanations of late-Holocene $\mathrm{CO}_{2}$ and $\mathrm{CH}_{4}$ increases be falsified? Holocene 21:865-879

Russell E (1983) Indian-set fires in the forests of northeastern United States. Ecology 64:76-88

Scarry CM (2003) Patterns of wild plant utilization in the Prehistoric eastern Woodlands. In: Minnis PE (ed) People and plants in ancient Eastern North America. Smithsonian Institution, Washington, pp 50-104

Schwindt DM, Bocinsky RK, Ortman SG, Glowacki DM, Varien MD, Kohler TA (2016) The social consequences of climate change in the central Mesa Verde region. Am Antiqu 81:74-96

Silver T (1990) A new face on the countryside: Indians, colonists and slaves in South Atlantic forests. Cambridge University Press, Cambridge, pp 1,500-1,800

Smith BD (2007) Niche construction and the behavioural context of plant and animal domestication. Evol Anthropol 16:188-199

Southgate (Russell) EWB (2006) Historical Ecology of American Chestnut (Castanea dentata). In: Steiner KC, Carlson JE (eds) Restoration of American Chestnut To Forest Lands: proceedings of a conference and workshop, May 4-6, 2004: the North Carolina Arboretum. Natural Resources Report NPS/NCR/ CUE/NRR-2006/001. National Park Service, Washington, DC, pp 13-19

Steckel RH, Rose JC (2005) The backbone of history: health and nutrition in the western hemisphere. Cambridge University Press, Cambridge

Stewart O (2002) Forgotten Fires: Native Americans and the transient Wilderness. University of Oklahoma Press, Norman

Tulowiecki SJ, Larsen CPS (2015) Native American impact on past forest composition inferred from species distribution models, Chautauqua County, New York. Ecol Monogr 85:557-581

Ubelaker DH (1992) The sources and methodology for Mooney's estimates of North American Indian Populations. In: Denevan WM (ed) The native population of the Americas in 1492. University of Wisconsin Press, Wisconsin, pp 243-288

Vale TR (2002) Fire, Native Peoples, and the natural landscape. Island, Washington

Viau AE, Gajewski K, Sawada MC, Fines P (2006) Millennial-scale temperature variations in North America during the Holocene. J Geophys Res 111:D09102

Wang GG, Knapp BO, Clark SL, Mudder BT (2013) The Silvics of Castanea dentata (Marsh.) Borkh., American Chestnut, Fagaceae (Beech Family). USDA Forest Service. General Technical Report (GTR)-SRS-173. Southern Research Station, Asheville

Warrick G (2008) A population history of the Huron-Petun, A.D. 500-1600. Cambridge University Press, Cambridge.

Webb T III (1988) Eastern North America. In: Huntley B, Webb T III (eds) Vegetation history. Handbook of Vegetation Sciences 7. Kluwer, Dordrecht, pp 155-192

Webb TIII, Bartlein P, Harrison S, Anderson KH (1993) Vegetation, lake levels and climate in eastern North America for the past 18,000 years. In: Wright HE Jr, Kutzbach JE, Webb T III, Ruddiman WF, Street-Perrott FA, Bartlein PJ (eds) Global climates 
since the last glacial maximum. University of Minnesota Press, Minneapolis, pp 415-467

Whitehead DR, Sheehan MC (1985) Holocene vegetational changes in the Tombigbee River valley, eastern Mississippi. Am Midl Nat 113:122-137

Whitney GG (1994) From coastal wilderness to fruited plain. Cambridge University Press, Cambridge

Williams M (1989) Deforestation: past and present. Prog Hum Geogr 13:176-208

Williams JW, Shuman BN (2008) Obtaining accurate and precise environmental reconstructions from the modern analog technique and North American surface pollen dataset. Quat Sci Rev 27:669-687

Williams JW, Shuman BN, Webb T III, Bartlein PJ, Leduc PL (2004) Late-Quaternary vegetation dynamics in North America: scaling from tax to biomes. Ecol Monogr 74:309-334
Williams JW, Grimm EC, Blois JL et al (2018) The Neotoma Paleoecology Database, a multiproxy, international, community-curated data resource. Quat Res 89:156-177. https://doi.org/10.1017/ qua.2017.105

Wycoff WW (1991) Black Walnut on Iroquoian landscapes. Northeast Indian Q 8:4-17

Zelinsky W (1973) The cultural geography of the United States, 1 st edn. Prentice Hall, New Jersey

Publisher's Note Springer Nature remains neutral with regard to jurisdictional claims in published maps and institutional affiliations. 